\title{
Introduction of Foreign Library Publishing Service and Its Enlightenment to China
}

\author{
Ligong Fang \\ Xuzhou College of Industrial Technology, Xuzhou 221140, China \\ fanglg@mail.xzcit.cn
}

Keywords: Library; Publishing Service; Cooperation Model; Enlightenment

\begin{abstract}
Digital publishing and open access to the movement to promote the University Library to begin to explore publishing services. This paper points out that the library publishing concept, introduces the foreign library academic library publishing services and foreign library publishing service cooperation model, discuss the foreign library publishing inspiration of service of Libraries in our country.
\end{abstract}

\section{Reasons for Libraries to Conduct the Publication Services}

Changes in Academic Communication. Academic communication refers to the process that scholars and researchers all over the world spread and share relevant academic researches through various channels. In the traditional printing age, academic communication is mainly conducted through open channels such as publishing books and periodicals, etc. With the expansion of the Internet, there are richer and richer channels for academic communication. For example, scholars can use communication tools such as the virtual network forum (BBS), blog, micro blog, e-mail and social network like SNS, and instant communication tools such as QQ and MSN, etc.

Publishers' Monopoly, Price Increase and Insufficient Library Funds. Academic publishers' monopoly over academic resources and constant price increase greatly restrict the conduction of academic communication and exchange activities as well as the possibility of conducting academic research innovation. Many organizations and institutions are trying to reform the current academic exchange and publish models. Some scholars believe that an ideal model is that commercialized publishers no longer participate in the process of exchanging and sharing academic information between scholars and researchers.

Promotion of Academic Search Engine. As a large amount of academic information of the digital format is on the Internet, commercially operated search engines begin to dabble into the search of academic information and resources relying on the massive web database and search technology. Many students, teachers and technology workers are becoming increasingly inclined to using academic search engine to search academic information. Of course, these academic search engines, whether free or not, have brought convenience for scientific research, but they also take away some readers that should originally belong to libraries.[1]

\section{The Concept and Features of Library Publishing}

Library publishing, refers to the relevant literature through the library publishing platform to publish digital publishing, in order to facilitate the exchange of academic information in the Internet Age. Library with its own library resources and human resources, IT resources independently or through a variety of possible forms of cooperation, and engaged in publishing activities related to the institutions to cooperate, and served as a role of organizer and publisher of academic content to possible to promote academic information and resources of the organization, dissemination and use, the expansion of academic research acquisition and communication. [1]

Library publication service has the following obvious features: 1, it has clear process to generate publishers; 2, From publishing information access port development become the birthplace of academic resources source directly unified publication and dissemination of all types of information publishing; (3) to peer review or college publishing form gives publishing information of the 
corresponding license. According to statistics, the United States has 55\% of the university library to carry out the business publishing, the publishing services and promote the library and the University Press of the depth of cooperation, some universities even through the merger and reorganization of the agency, the press was placed under the library publishing service. Either cooperative or merger, through the combination and use the advantages of library information technology and digital workflow, thus creating unique publishing service field is one of the common characteristics of the service publishing in the university library.

\section{Introduction of Academic Library Publishing Service in Foreign Libraries}

The report of the American Research Library Association in 2008 showed that $71 \%$ of the published academic books were published in the university libraries. It can be seen from this, the library of American University to carry out academic book publishing service has been very common. In 2012, the successful strategy of Library publishing service, published by the publishing house of Purdue University publishing house, has been discussed in detail.

The new model of publishing group to the campus within the academic community to provide open access to digital publishing services, to support the wide dissemination of the university research results, through the advanced technology application to the development of academic digital publishing is set up by the library of the University of California. California university library provides a complete set of publishing services, including a system level publishing platform, as well as a number of publishing projects with the California University press. Publication serves as a sustainable academic publishing model, and its implementation provides users with the service required for university research and teaching. [2]

Massachusetts Institute of Technology Publishing Service Libguides open source software system is adopted, create the publication of specialized service Libguides platform, comprising special topics, pre-paring your research for publication, sakthe experts three modules, detailed introduced the open access publishing resources and service process. Massachusetts Institute of technology to achieve the open access publishing the integration services, support for multiple channels of open access publishing, service personnel a clear division of labor, the service process is concise and clear, funding arrangement is compact and reasonable, effectively promotes the school scientific research, thesis and course software of communication.

Australian National Library in the process of publishing has experienced three stages: The first is the installation of publishing software platform in the library server, then establish a pilot publishing service, and finally combined with the JASAL journal team to develop a set of sustainable operation mode. In addition, invited members of the association to the identity of the authors, reviewers, editors, proofreaders, for testing, and in the association held the conference demonstrates the publishing system. Then the association began to take over and use the system to publish new journals. Journal Editor Team in the experience of the first published online work, although encounter difficulties in terms of upload and download information and documentation, but overall was relatively smooth, compared with before, the periodical editors don't need rummage in the drawer in the article, do not have to worry about the missing issue.

\section{Foreign Library Publishing Service Cooperation Model}

In From the Service Providers to the Content Producers: Cooperative Library Open Access Publishing New Opportunities, Scholars Janneke Ademad pointed out that for the current library publishing service development mode analysis and summarizes the published service cooperation model library: Library Press; Library-Publishing House Cooperative; Library, Publishing House and the Three Party Cooperation.

Library Press. This model refers to the establishment of a new publishing house in the library or a temporary suspension of business of publishing house in the library to carry out the work of publishing. This model has a serious dependence on the library's own resources, facilities, and inter departmental cooperation. 
Library-Publishing House Cooperative. This pattern is referring to the library and the press to negotiate, a framework for cooperation in the business and to achieve cooperation between the two can be in business to carry out mutual sharing and use has already had the basic resources, professional skills and service.

Publishing House and the Three Party Cooperation. In the library and publishing house and engage in publication services, invited or the third party agencies or departments to absorb into the reference for, the third party agencies or departments can be the scholarly publishing office, office of academic exchange, to engage in the publication of the relevant agencies or organizations. [1]

\section{The Enlightenment of Foreign Library Publishing Service to the Library of Our Country}

Repositioning the Library Properties. The dominant power of open access is the leading power of the future academic information exchange and service. So the library should participate actively and actively guide, and actively explore the open channel resources new service ability, must have the courage to bear the open access policy proposals, open access to the promoter, new open research information environment, the founder of multiple tasks, in policy formulation, information organization and promote the library alliance aspects make there is conducive to the development of Open Access initiatives. Especially in the construction of university library knowledge base, can integrate the field of academic research activities, teaching activities, scientific research management, promote academic exchange and integration. [3]

Do Their Best to Strengthen Cooperation. Library publishing services to carry out not only to obtain the support of the leadership, libraries and scholars, should also strengthen the library and the press and information technology department, school research institutions and academic group cooperation, play to their respective advantages can make the project carried out smoothly and get work. Libraries play a finishing the library collection resources digitization and resource rich experience and expertise, press play the editing and publishing specialty, information technology sector to play its technical expertise, research institutions and academic groups play their professional advantages, collaboration of different departments, to establish a scientific and reasonable publishing platform, shared among the members of the school academic resources. To expand the scope of cooperation, to build a certain area, the scope of the University, scientific research institutions, academic resources of large-scale joint platform to achieve a wider range of academic resources open to the spread. [4]

Probe Into the New Mode of Library Publishing Service Development. Library bears the responsibility of knowledge transmission, information service and academic communication. Library publishing service is a new mode of library service in the Internet age, which extends the connotation and extension of library service. But due to differences in domestic and foreign cultural and publishing system, we cannot simply apply the foreign libraries publishing mode for the development of services, and should be combined with the actual situation of our country universities, libraries and publishers, and actively explore the development mode suitable for the situation of our country.

Clear Mission, Rational Planning. When the University Library in our country carries out the publishing activities, we should also make clear the purpose and mission of the University, and carry out the short-term and medium and long-term planning. With teachers and students to focus on the issue of investigation and analysis, on this basis, combined with its own advantages, the first easy after the difficult, after simple, from easy, low cost, less progress resistance of the project. At the same time, strengthen the library propaganda work, strive for the relevant departments of the school and the teachers and student's recognition and support, the time is ripe, the allocation of resources more fully, and then start the subsequent publishing activities. [5]

Realize the Sustainable Development of the Library Industry Based on the Commercial Operation Mode. Although the library is not a profit-making organization, but due to budget constraints, the business model must be integrated into its project operation, in order to achieve the sustainable development of the project. The commercial operation mode of the library project can be carried out from the following aspects: (1) make the project budget plan. Budget should include 
project managers, researchers, wages, welfare costs and meeting fees, travel expenses, software licensing fees, consulting fees, management fees, in the actual implementation process, strict budget in accordance with the use of project funds, as far as possible to achieve cost saving.(2) Design Library publishing best practice model, to ensure that the purchase of academic publications in a reasonable price range, to protect the rights of the long-term use of libraries, to speed up the process of open access.(3) Expand the social influence and popularity of the library project. Actively strive for all kinds of government, public welfare or commercial investment and financing opportunities for the development of the project to lay a solid foundation for the development of the library and financial resources. [6]

\section{References}

[1] Chenguo Song. Research on the service mode of Library publishing in the digital age [D]. Liaoning Normal University.China.2013.p.28

[2] Rui Wei,Jingli Chu. Open Access of Academic Monographs and Publishing Services in American University Libraries. Journal of Academic Libraries.(2014) No. 3, p. 17-22.

[3] Huifang Zhao, Yiguo Mao. New Model of Scholarly Communication:Library Publishing Services. Journal of Academic Libraries.(2012) No. 2, p. 13-17.

[4] Jingqiu Kui. Study of the British University Library Publishing Practice Based The Library ubkshing Directory. Library Forum .(2015)No. 2,p.125-131.

[5] Qing Qiang.Study on LPC projectof library publishing. Researches in library science .(2014)No.18,p. 88-92.

[6] Feng Wen. Exploration on the publishing service model of University Library under the digital environment.vol.25(2015)No.1,p:58-59. 